\title{
Multimedia-based group guidance in assisting children reaching puberty in Central Lombok
}

\author{
Fitri Aulia', Musifuddin ${ }^{2}$, Umi Aisyah³, Marfuatun ${ }^{4}$, I Dewa Putu Partha \\ 1,2,4,5 Universitas Hamzanwadi Lombok \\ ${ }^{3}$ UIN Raden Intan Lampung \\ fitriaulia04@gmail.com
}

Submitted: 30-06-2021, Revised: 22-11-2021, Accepted: 26-11-2021

\begin{abstract}
This study aims to determine the effect of group guidance in assisting children reaching puberty in Central Lombok. The strategy uses group guidance and the media uses youtube videos and hands-on practice with tutorials. Group guidance services function as an understanding and prevention of deviant behavior during the transition from childhood to early adulthood. The research method used is experimental with pretest and posttest designs. Subjects consisted of 6 students aged 9-13 years. The topics discussed are 1) what and how puberty is, (2) the influence of puberty in the social environment, 3) the meaning of menstruation, and how to live a healthy lifestyle. Based on the data, the results of the pretest showed an average value of $21 \%$ and a standard deviation of $2.44 \%$. The posttest results showed an average value of $24.8 \%$, standard deviation of $4.49 \%$. It shows that the enactment of group guidance is effective in increasing the understanding of puberty teenagers. Based on the satisfaction questionnaire after being given group guidance, a score of 20-24 is included in the very good category.
\end{abstract}

Keywords: Group Guidance; Multimedia; Teenager Puberty

\section{Introduction}

One of the cultures in the Sasak community (a tribe in Lombok) perceived that girls are not fully entitled to higher education like boys. Although over time this condition began to improve. Over time, it enhances to be a better situation. But in some community groups and household heads, were still reluctant to send their daughters to higher education. This trigger the high number of early marriages in Lombok. After a girl's menstruation, she will be called "Dedare" by society. Dedare means that girls are ready to come into the age of marriage. Menstruation is the main sign of girls reaching puberty. Unfortunately, this understanding is not accompanied by sufficient information about what menstruation is, what changes occur in their bodies when it comes, what the psychological condition during menstruation is, and what if they get married when they are menstruating. There is a knowledge gap among young women in Lombok. Adolescence is the phase of life stretching between childhood and adulthood and its definition has long posed a conundrum (Chiasson \& Tristan, 2012; Kinghorn et al., 2018; Levy, 2016; McDonagh et al., 2018). Adolescence encompasses elements of biological growth and major social role transitions (Belcher et al., 2021; Lerner et al., 2018; Patton et al., 2016; Petersen et al., 2017). Both of which have changed in the past century. Earlier puberty has accelerated the onset of adolescence in nearly all populations. (Sawyer et al., 2018)

The results of the observation revealed that the menstrual rate among teenage girls in Lombok was accelerating. Several 5th-grade elementary school children claimed to have menstruated. This velocity became a new phenomenon that resulted in the gap between young women and the information provided by their parents increasing their concern. At the age of early menstruation (menarche), teenagers experience a very drastic swiftness compared to the previous generation. (Cowan \& Richardson, 2019; Stattin \& Magnusson, 2018; Viner et al., 2017). The trigger factors are various such as genetics, nutritional status, and environmental factors (Otobo et al., 2018; Shalitin \& Kiess, 2017; Tiffon, 2018). Good or bad nutritional status is influenced by the type of food consumed (Depauw \& Oxley, 2019; Michael et al., 2019; Shalitin \& Kiess, 2017). Foods made from junk food are very well- 
known for the lifestyle of modern society. Junk food is all types of food that contain high amounts of sugar, fat, and calories, but contain the least micronutrients (Anita \& Simanjuntak, 2018). The content of micronutrients are vitamins, minerals, amino acids, and fiber. The content of fast food will trigger the production of hormones that play a role in the maturation of the formation and formation of estrogen. This is the main hormone that controls physical and non-physical teenagers during puberty. The habit of consuming processed food has a major effect on the speed of early puberty in teenage girls (Kustin et al., 2017; Mendle et al., 2019).

The transition from childhood to adolescence is a critical transitional period for girls, and as they experience these changes, having knowledge of, and being able to practice, good menstruation hygiene management is crucial. The objective of this study is to understand in and out of school teenagers' menstrual hygiene utilize practice, sources of information, and attitudes towards menstruation. Menarche is the first menstrual cycle or first menstrual bleeding in women. Ironically, the speed of menstruation will cause gaps in three aspects of growth, namely biological, psychological, and social (Chinyama et al., 2019; MacRae et al., 2019; Phillips-Howard et al., 2016; Sychareun et al., 2020). Menarche is also considered to trigger the risk of breast cancer (Djannah \& Solikhah, 2019) because it is influenced by a progesterone cycle of $6.4 \mathrm{nmol} / \mathrm{liter}(2.0 \mathrm{ng} / \mathrm{ml})$ which is contemplated to indicate an anovulatory cycle (Liu et al., 2020). The condition of high levels of the hormone progesterone will greatly affect puberty. Women with early menarche experience stimulation of the hormone estrogen which tends to be high, until the age of 30 . This is a risk that needs to be anticipated in accompanying the child's puberty (Léger \& Carel, 2016; Rehman \& Sultana, n.d.; Sopher et al., 2021; Sultan et al., 2018).

Teenagers often experience volatile emotions. Some even claim to lose the mood when completing tasks for no apparent reason. Adolescence is a transition period from childhood to early adulthood that has many risks (Boislard et al., 2016; Croft et al., 2019; Wisk \& Weitzman, 2016; Womack et al., 2016). Teenagers are very easy to get depressed (Anyan \& Hjemdal, 2016; Bernaras et al., 2019; Thabrew et al., 2018; Wang et al., 2018). Therefore puberty requires a lot of significant information (Kheirollahi et al., 2017; Kustin et al., 2017). Adolescence is a span of change from youth to maturity, where at this time teenagers experience rapid emotional changes, both positive and negative (Dahl et al., 2018). They experienced significant physical and cognitive changes during puberty (Bello et al., 2017). Sex education in juvenile is vital (Alimoradi et al., 2017). Ignorance of sexual development in the child's body will adversely affect the process of stimulating secondary sexual characteristics, accelerated growth, and changes in body composition during adolescence (Mason et al., 2020). Youngsters are often close themselves off from adults, especially parents (Bello et al., 2017). They are dubious to talk about the changes that occur within them. This results in high anxiety and leads to mistakes in making decisions.

Puberty tends to begin between the ages of 8-13 in girls and 9-14 years for boys (Hughes et al., 2017). However, this study has been re-updated and concludes that puberty in girls has changed about three months earlier each decade, since the 1970s. Researchers from the University of Copenhagen conducted a review of data from 38 studies involving tens of thousands of girls around the world. Meanwhile, according to data from Kompas.com, information is obtained that girls experience puberty almost one year earlier than girls 40 years ago.

Teenagers at puberty have brief knowledge. This is a phenomenon that needs to be considered by various parties. Schools are one of the many parties that exist in increasing the knowledge of the kids. The main tasks and functions can be provided by school counselors, with support from the assorted group. Counseling guidance programs by counselors are urgently needed by teenagers, to help them manage depression in a more positive direction. 
(Abu Bakar, 2019). Group counseling services for teenage adolescence have a huge impact on changes in teenagers' demeanor such as increasing their knowledge about the law of associating with the opposite sex. In the three cycles, it was found that the increase in students' understanding was 33.3\% from 100\% (Mutiah, 2020). Most male and female students who have reached puberty do not understand the changes (physical, psychological and emotional) that occur to them (Akbari Kamrani \& Farid, 2017; Currie, 2019; de Vries, 2020; Kaltiala et al., 2020). Teenagers tend to be closed with their parents when they feel physical changes (Wardah, 2018).

Services with group settings require support so that the goals of the service can be achieved optimally. The use of multimedia-based media will add to the attractiveness of the service provided. Teenagers are decided as the target group guidance services. Multimedia provides many interesting nuances in the service delivery process. Multimedia used in this service will take advantage of videos on youtube. Guidance and counseling services utilize YouTube media in the form of animated videos about the physical changes of teenagers during puberty. The selection of the video is based on several reasons; teenagers have a high interest in the use of social media (Balleys, 2017; Sari \& Margana, 2019; Westenberg, 2016). A report from Defy Media states that $96 \%$ of the 13-14-year-old age group, on average, spends 11 hours a week watching online videos. Youtube is considered massive in establishing communication with teenagers. Six out of ten teenagers aged 13-18 years form action from watching videos on Youtube (Wei et al., 2020). Based on these data, YouTube is considered to have a major influence on the process of forming knowledge in them. It is included in the implementation of group guidance services on teenager puberty. Youtube does not only have negative impacts like harms people who access it but also has positive impacts like building new knowledge quickly. It is recognized as very effective in increasing student participation in class and various other educational activities. This includes group guidance services using Youtube which is recognized as being quite effective in conveying information (Gear, 2019; Jackman, 2019; Johnson et al., 2021; Klobas et al., 2018). The elevated positive impact on the use of YouTube as a medium of education and guidance for students is a very interesting and argumentative choice in this study. That is by using Youtube as an effective tool to achieve an effective understanding of puberty among students.

\section{Methods}

The design of this study was experimental, with the research subjects totaling six teenagers aged 9-13 years. Subjects were given a pretest and then given a group guidance intervention. The media used are videos and simulations on how to maintain personal hygiene during puberty directly. Some of the topics that will be discussed are 1) what and how puberty is, (2) the influence of puberty in the social environment, 3) the meaning of menstruation, and how to live a healthy lifestyle. At the end of the intervention, a post-test will be given. The design of this research can be seen from the following figure:

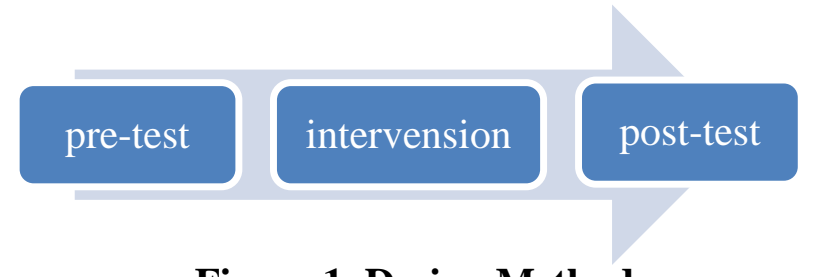

Figure 1. Design Method 
Pretest and posttest will be conducted by distributing the instrument in the form of a questionnaire. The following is the intervention plan:

Table 1. Research Design Interventions

\begin{tabular}{lcc}
\hline \multicolumn{1}{c}{ Topic } & Duration & Strategy and media \\
\hline What is puberty, and how is puberty? & $60 \mathrm{~min}$ & Video \\
\hline How does puberty affect the social environment? & $60 \mathrm{~min}$ & Video \\
\hline What is menstruation and what is a healthy lifestyle? & $60 \mathrm{~min}$ & Simulation and Video \\
\hline
\end{tabular}

Covariance data analysis was used to control for differences between the two intervention and control groups before the intervention, and other factors, such as age, father's occupation, mother's education, and economic status. The data were analyzed by looking at the hypothesis with the t-test and table test.

Table 2: Pretest and Posttest Instrument Grid

\begin{tabular}{|c|c|c|c|c|}
\hline Num & Aspect & Indicator & Item & Total \\
\hline \multirow[t]{3}{*}{1} & \multirow[t]{3}{*}{ Physical } & a. Health & 1,22 & 2 \\
\hline & & b. Non-physical condition & 2,3 & 2 \\
\hline & & c. Physical Change & $4,6,23,24$ & 4 \\
\hline \multirow[t]{3}{*}{2} & \multirow[t]{3}{*}{ Psychic } & a. $\quad$ Personality & $5,7,25,26$ & 3 \\
\hline & & b. Mental or soul & $8,9,10,28,29$ & 4 \\
\hline & & c. Nature & $11,12,13,14$ & 4 \\
\hline \multirow[t]{3}{*}{3} & \multirow{3}{*}{$\begin{array}{l}\text { Social- } \\
\text { emotional } \\
\text { and } \\
\text { cognitive }\end{array}$} & $\begin{array}{l}\text { a. Understanding of the novelty of } \\
\text { puberty }\end{array}$ & 15,16 & 2 \\
\hline & & b. Ability to interact & 17,18 & 2 \\
\hline & & $\begin{array}{l}\text { c. Knowing the difference between } \\
\text { men and women }\end{array}$ & $19,20,27,38$ & 4 \\
\hline \multirow[t]{2}{*}{4} & Spiritual & $\begin{array}{l}\text { a Understanding the values of } \\
\text { worship }\end{array}$ & $21,22,30$ & 3 \\
\hline & & Total item & & 30 \\
\hline
\end{tabular}

The four aspects above will be absorbed in the form of an instrument on teenagers' understanding of puberty.

\section{Results and Discussion}

The four aspects studied in this study are physical, psychological, social, emotional, and spiritual aspects.

Table 3. Comparison of Pretest-Posttest

\begin{tabular}{ccccc}
\hline Subjects & Pre-test & Post-test & Mean & Standard Deviation \\
\hline 1 & 20 & 30 & & \\
\hline 2 & 18 & 20 & & \\
\hline 3 & 24 & 30 & Pre-test $\mathrm{M}=21 \%$ & Pre-test $\mathrm{SD}=2.44$ \\
\hline 4 & 24 & 26 \\
\hline 5 & 20 & 22 & & \\
\hline 6 & 20 & 21 & & \\
\hline
\end{tabular}


The pretest data showed an average value of $21 \%$ and a standard deviation of $2.44 \%$. The posttest results showed an average value of $24.8 \%$, a standard deviation of $4.49 \%$. This shows that the implementation of group guidance is effective in increasing the understanding of teenager puberty.

Table 4. Score and Gain Pretest-Posttest

\begin{tabular}{cccc}
\hline Subjects & Pre-test & Post-test & $\left(\sum \boldsymbol{d}\right)$ \\
\hline 1 & 20 & 30 & 10 \\
\hline 2 & 18 & 20 & 2 \\
\hline 3 & 24 & 30 & 6 \\
\hline 4 & 24 & 26 & 2 \\
\hline 5 & 20 & 22 & 2 \\
\hline 6 & 20 & 21 & 1 \\
\hline $\mathrm{N}=6$ & $\mathrm{X}_{1}=126$ & $\mathrm{X}_{2}=149$ & $\sum_{\mathrm{d}}=23$ \\
\hline
\end{tabular}

Table 4 is the result of the pre-test and post-test scores for the six subjects. The total pretest score of 6 subjects showed a total score of 126, while the posttest showed a total score of 149. These results indicated an increase in the pretest and posttest scores for the six subjects. An increase in score of 23, means an increase in understanding after being given treatment.

The results of the t-test that have been carried out can be seen from the following table:

Table 5. One-Sample Test

\begin{tabular}{cc}
\hline $\mathbf{t}$ & Sig. \\
\hline 3,149 & 2,571 \\
\hline
\end{tabular}

The results of data analysis obtained a t-count of 3,149 while the number in the table of $t$ values for the one-tailed test with a significance level of $0.05(5 \%)$ on d.b N-1 $=5$ is 2.571. Therefore, the results of data analysis of 3.149 are above the limit number of rejection of the null hypothesis which is 2.571 ( $\mathrm{t}$-count $>\mathrm{t}$-table), so this study is significant.

The results showed that teenagers need sufficient information about puberty, to prepare themselves for early adulthood. The high number of anxiety experienced by teenagers will adversely affect their personal development. Weak teenager personality development will affect its role in society as the next generation. Between being a superior positive generation or just being a teenager without any contribution, or even disturbing the social environment. In research that focuses on teenagers in the era of the industrial revolution 4.0, teenagers in the social aspect are characterized by their good adaptability and their ease of forming friendships with new people (Adiansah et al., 2019). However, this does not apply to teenagers in the Koppang area of Central Lombok. The progress of knowledge and understanding has not been well-formed. This is reflected in the data on the results of the teenager pretest which only reached a score of $21 \%$. Still far from the minimum categorization value.

The results of the interviews showed that the problems of teenagers during puberty became closed to the environment. Teenagers are hesitant to tell their parents about the physical, hormonal, and biological changes they feel. Teenagers experience anxiety during their first menstruation and cause them not to know what and how to deal with the new situation. They become shy with their peers and withdraw from social circles. They also experience failure to express themselves in the environment. For example, withdrawing from the environment or being very aggressive with the opposite sex. 
The rate of menstruation in children was found in the case of this study, two out of six subjects experienced early menstruation at the age of 10 years. The factors behind early menstruation are food, parenting patterns, social environment, and gadgets. Another phenomenon is the limited privacy space at home, caused by the structure of a large family living in the same house. Teenagers must sleep in the same room with their parents.

The role of parents in assisting their children during puberty has a high percentage in their development, especially mothers. Parents' misunderstanding will increase the confusion of teenagers in carrying out daily routines both in the family environment and in their social environment. Physical, biological, social-emotional, and spiritual changes affect each other. The high level of anxiety experienced by teenagers will harm their personal development. In this case, it was found that the subject did not tell his mother on the first day of menstruation. The subject chooses to remain silent and inappropriately handles cases, resulting in them being surprised by physical changes when they feel vulnerable.

\section{Conclusions and Suggestions}

Puberty for teenagers is a colossal task for all parties, such as the task for teenagers themselves, parents, teachers in schools, and the community. Pretest data shows that the level of understanding of teenagers about puberty is in a low category. If you do not get the right information, teenagers at puberty will make the wrong attitude. The subject also revealed that the level of understanding of their parents is still minimal. Parents have difficulty in educating their daughters to deal with puberty and menstruation on the first day.

This study confirms that the phenomenon of teenager puberty is accelerating. As a result of this momentum many problems were found, and the most basic of which was a poor understanding of the impact of puberty itself. In dealing with puberty, they need a lot of information about themselves, such as physical, biological, psychological, socio-emotional, religious, and other aspects of development. Counselors play a vital role; they must always be ready to provide education to young women who reach puberty. Teenagers can grow positively at puberty if they get assistance. Juvenile who do not get information about themselves from experts, or educational media will experience a lot of pressure and will affect the social role of minors in the family and society. This research needs to be continued, by examining the background of each youngster in receiving information about pubescence.

\section{Reference}

Abu Bakar, A. S. (2019). Implementasi layanan bimbingan konseling islami untuk mengatasi depresi pada fase dewasa awal studi deskriptif di hospital Bintulu, Sarawak, Malaysia. UIN Sunan Gunung Djati Bandung.

Adiansah, W., Setiawan, E., Kodaruddin, W. N., \& Wibowo, H. (2019). Person in environment remaja pada era revolusi industri 4.0. Focus: Jurnal Pekerjaan Sosial, 2(1), 47-60.

Akbari Kamrani, M., \& Farid, M. (2017). Chronological age and puberty coping strategy among Iranian teenager females. International Journal of School Health, 4(4), 1-6.

Alimoradi, Z., Kariman, N., Simbar, M., \& Ahmadi, F. (2017). Empowerment of teenager girls for sexual and reproductive health care: A qualitative study. African Journal of Reproductive Health, 21(4), 80-92.

Anita, S., \& Simanjuntak, Y. T. (2018). The correlation between junk food consumption and age of menarche of elementary school student in Gedung Johor Medan. Unnes Journal of Public Health, 7(1), 21-24.

Anyan, F., \& Hjemdal, O. (2016). Teenager stress and symptoms of anxiety and depression: Resilience explains and differentiates the relationships. Journal of Affective 
Disorders, 203, 213-220.

Balleys, C. (2017). Teen boys on youtube: Representations of gender and intimacy. In Mediated Intimacies (pp. 227-239). Routledge.

Belcher, B. R., Zink, J., Azad, A., Campbell, C. E., Chakravartti, S. P., \& Herting, M. M. (2021). The roles of physical activity, exercise, and fitness in promoting resilience during adolescence: effects on mental well-being and brain development. Biological Psychiatry: Cognitive Neuroscience and Neuroimaging, 6(2), 225-237.

Bello, B. M., Fatusi, A. O., Adepoju, O. E., Maina, B. W., Kabiru, C. W., Sommer, M., \& Mmari, K. (2017). Teenager and parental reactions to puberty in Nigeria and Kenya: A cross-cultural and intergenerational comparison. Journal of Teenager Health, 61(4), S35-S41.

Bernaras, E., Jaureguizar, J., \& Garaigordobil, M. (2019). Child and teenager depression: a review of theories, evaluation instruments, prevention programs, and treatments. Frontiers in Psychology, 10, 543.

Boislard, M.-A., Van de Bongardt, D., \& Blais, M. (2016). Sexuality (and lack thereof) in adolescence and early adulthood: A review of the literature. Behavioral Sciences, $6(1), 8$.

Chiasson, P., \& Tristan, J. (2012). Relational thinking styles and natural intelligence: Assessing inference patterns for computational modeling. In Relational Thinking Styles and Natural Intelligence: Assessing Inference Patterns for Computational Modeling. IGI Global. https://doi.org/10.4018/978-1-4666-0972-3

Chinyama, J., Chipungu, J., Rudd, C., Mwale, M., Verstraete, L., Sikamo, C., Mutale, W., Chilengi, R., \& Sharma, A. (2019). Menstrual hygiene management in rural schools of Zambia: A descriptive study of knowledge, experiences, and challenges faced by schoolgirls. BMC Public Health, 19(1), 1-10.

Cowan, C. S. M., \& Richardson, R. (2019). Early-life stress leads to sex-dependent changes in pubertal timing in rats that are reversed by a probiotic formulation. Developmental Psychobiology, 61(5), 679-687.

Croft, J., Heron, J., Teufel, C., Cannon, M., Wolke, D., Thompson, A., Houtepen, L., \& Zammit, S. (2019). Association of trauma type, age of exposure, and frequency in childhood and adolescence with psychotic experiences in early adulthood. JAMA Psychiatry, 76(1), 79-86.

Currie, C. (2019). Development is not the same as aging: The relevance of puberty to the health of teenagers. Springer.

Dahl, R. E., Allen, N. B., Wilbrecht, L., \& Suleiman, A. B. (2018). Importance of investing in adolescence from a developmental science perspective. Nature, 554(7693), 441450.

de Vries, A. L. C. (2020). Challenges in timing puberty suppression for gendernonconforming teenagers. Pediatrics, 146(4).

Depauw, E., \& Oxley, D. (2019). Toddlers, teenagers, and terminal heights: The importance of puberty for male adult stature, Flanders, 1800-76. The Economic History Review, 72(3), 925-952.

Djannah, S. N., \& Solikhah, S. (2019). Early menarche with breast cancer awareness: A literature review. 2019 Ahmad Dahlan International Conference Series on Pharmacy and Health Science (ADICS-PHS 2019): Advances in Health Sciences Research, 18.

Gear, S. (2019). Like, comment, subscribe the role of youtube in identity development.

Hughes, K., Bellis, M. A., Hardcastle, K. A., Sethi, D., Butchart, A., Mikton, C., Jones, L., \& Dunne, M. P. (2017). The effect of multiple adverse childhood experiences on health: A systematic review and meta-analysis. The Lancet Public Health, 2(8), e356-e366.

Jackman, W. M. (2019). YouTube usage in the university classroom: An argument for its 
pedagogical benefits. IJET, 14(9), 157-166.

Johnson, K. F., Brookover, D. L., Borden, N. J., Worth, A. K., Temple, P., \& Mahan, L. B. (2021). What youtube narratives reveal about online support, counseling entrance, and how Black Americans manage depression symptomatology. Informatics for Health and Social Care, 46(1), 84-99.

Kaltiala, R., Bergman, H., Carmichael, P., de Graaf, N. M., Egebjerg Rischel, K., Frisen, L., Schorkopf, M., Suomalainen, L., \& Waehre, A. (2020). Time trends in referrals to child and teenager gender identity services: A study in four Nordic countries and in the UK. Nordic Journal of Psychiatry, 74(1), 40-44

Kheirollahi, F., Rahimi, Z., Arsang-Jang, S., Sharifirad, G., Sarraf, P., \& Gharlipour, Z. (2017). Puberty health status among teenager girls: A model-based educational program. International Journal of Pediatrics, 5(7), 5369-5378.

Kinghorn, A., Shanaube, K., Toska, E., Cluver, L., \& Bekker, L.-G. (2018). Defining adolescence: Priorities from a global health perspective. The Lancet Child \& Teenager Health, 2(5), e10.

Klobas, J. E., McGill, T. J., Moghavvemi, S., \& Paramanathan, T. (2018). Compulsive youtube usage: A comparison of use motivation and personality effects. Computers in Human Behavior, 87, 129-139.

Kustin, K., Wahyuningtyias, F., \& Munawir, A. (2017). The effects of junk food consumption on incidence of early puberty in teenager females. Health Notions, 1(4), 408-413.

Léger, J., \& Carel, J.-C. (2016). Precocious puberty. In Puberty (pp. 137-154). Springer.

Lerner, R. M., Brindis, C. D., Batanova, M., \& Blum, R. W. (2018). Teenager health development: A relational developmental systems perspective. Handbook of Life Course Health Development, 109-121.

Levy, L. (2016). Thinking with beauvoir on the freedom of the child. Hypatia, 31(1), 140155.

Liu, M., Murthi, S., \& Poretsky, L. (2020). Focus: Sex \& reproduction: Polycystic ovary syndrome and gender identity. The Yale Journal of Biology and Medicine, 93(4), 529.

MacRae, E. R., Clasen, T., Dasmohapatra, M., \& Caruso, B. A. (2019). "It's like a burden on the head": Redefining adequate menstrual hygiene management throughout women's varied life stages in Odisha, India. PLoS One, 14(8), e0220114.

Mason, K. A., Schoelwer, M. J., \& Rogol, A. D. (2020). Androgens during Infancy, childhood, and adolescence: Physiology and use in clinical practice. Endocrine Reviews, 41(3), bnaa003.

McDonagh, J. E., Ambresin, A.-E., Boisen, K. A., Fonseca, H., Kruse, P. J., Meynard, A., Stronski, S., Michaud, P.-A., \& Takeuchi, Y. L. (2018). The age of adolescence and young adulthood. The Lancet Child \& Teenager Health, 2(4), e6.

Mendle, J., Ryan, R. M., \& McKone, K. M. P. (2019). Early menarche and internalizing and externalizing in adulthood: Explaining the persistence of effects. Journal of Teenager Health, 65(5), 599-606.

Michael, J. D., Baruselli, P. S., \& Campanile, G. (2019). Influence of nutrition, body condition, and metabolic status on reproduction in female beef cattle: A review. Theriogenology, 125, 277-284.

Mutiah, R. (2020). Penerapan bimbingan konseling kelompok terhadap remaja dalam menghadapi pubertas di Desa Tanobato Kecamatan Panyabungan Selatan. IAIN Padangsidimpuan.

Otobo, T. M., Paul, J. N., \& Isikaku, O. O. (2018). Age at menarche in nigerian teenager girls case study: (Igbo, Yoruba, Hausa and Engenni Tribes of Nigeria). European Journal of Pharmaceutical and Medical Research, 5(9), 152-160. 
Patton, G. C., Sawyer, S. M., Santelli, J. S., Ross, D. A., Afifi, R., Allen, N. B., Arora, M., Azzopardi, P., Baldwin, W., \& Bonell, C. (2016). Our future: A lancet commission on teenager health and wellbeing. The Lancet, 387(10036), 2423-2478.

Petersen, A. C., Kennedy, R. E., \& Sullivan, P. (2017). Coping with adolescence. In Teenager stress (pp. 93-110). Routledge.

Phillips-Howard, P. A., Caruso, B., Torondel, B., Zulaika, G., Sahin, M., \& Sommer, M. (2016). Menstrual hygiene management among teenager schoolgirls in low-and middle-income countries: Research priorities. Global Health Action, 9(1), 33032.

Rehman, R., \& Sultana, N. (n.d.). Physical development. Teenager psychology, 25.

Sari, Y. N., \& Margana, M. (2019). YouTube as a learning media to improve the student's speaking ability in 21st century. Journal of English Language Teaching and Linguistics, 4(2), 263.

Sawyer, S. M., Azzopardi, P. S., Wickremarathne, D., \& Patton, G. C. (2018). The age of adolescence. The Lancet Child \& Teenager Health, 2(3), 223-228.

Shalitin, S., \& Kiess, W. (2017). Putative effects of obesity on linear growth and puberty. Hormone Research in Paediatrics, 88(1), 101-110.

Sopher, A. B., Oberfield, S. E., \& Witchel, S. F. (2021). Disorders of puberty in girls. Seminars in Reproductive Medicine.

Stattin, H., \& Magnusson, D. (2018). Pubertal maturation in female development. Routledge.

Sultan, C., Gaspari, L., Maimoun, L., Kalfa, N., \& Paris, F. (2018). Disorders of puberty. Best Practice \& Research Clinical Obstetrics \& Gynaecology, 48, 62-89.

Sychareun, V., Chaleunvong, K., Essink, D. R., Phommavongsa, P., \& Durham, J. (2020). Menstruation practice among school and out-of-school teenager girls, Lao PDR. Global Health Action, 13(sup2), 1785170.

Thabrew, H., Stasiak, K., Hetrick, S. E., Wong, S., Huss, J. H., \& Merry, S. N. (2018). EHealth interventions for anxiety and depression in children and teenagers with longterm physical conditions. Cochrane Database of Systematic Reviews, 8.

Tiffon, C. (2018). The impact of nutrition and environmental epigenetics on human health and disease. International Journal of Molecular Sciences, 19(11), 3425.

Viner, R. M., Allen, N. B., \& Patton, G. C. (2017). Puberty, developmental processes, and health interventions. Child and Teenager Health and Development, 8, 1841.

Wang, P., Wang, X., Wu, Y., Xie, X., Wang, X., Zhao, F., Ouyang, M., \& Lei, L. (2018). Social networking sites addiction and teenager depression: A moderated mediation model of rumination and self-esteem. Personality and Individual Differences, 127, $162-167$.

Wardah, A. (2018). Pemahaman diri siswa SMP tentang masa pubertas (baligh) sebagai fondasi layanan bimbingan dan konseling. Jurnal Bimbingan Dan Konseling ArRahman, 4(2), 88-93.

Wei, Q., Wu, M., Li, Y.-L., Rao, R., Li, S., Cen, Q., Wu, H., Lv, L., Huang, M., \& Ge, Y.-P. (2020). Physical deviation and precocious puberty among school-aged children in Leshan City: An investigative study. Journal of International Medical Research, 48(8), 0300060520939672.

Westenberg, W. M. (2016). The influence of youtubers on teenagers: Descriptive research about the role youtubers play in the life of their teenage viewers. The University of Twente.

Wisk, L. E., \& Weitzman, E. R. (2016). Substance use patterns through early adulthood: results for youth with and without chronic conditions. American Journal of Preventive Medicine, 51(1), 33-45

Womack, S. R., Shaw, D. S., Weaver, C. M., \& Forbes, E. E. (2016). Bidirectional associations between cannabis use and depressive symptoms from adolescence 
through early adulthood among at-risk young men. Journal of Studies on Alcohol and Drugs, 77(2), 287-297. 